\title{
Job demands, job control, and social support as predictors of job satisfaction and burnout in Croatian palliative care nurses
}

\author{
Ivana Tucak Junaković and Ivana Macuka \\ University of Zadar Department of Psychology, Zadar, Croatia
}

[Received in May 2021; Similarity Check in May 2021; Accepted in August 2021]

\begin{abstract}
The Job Demands-Control-Support (JDCS) model has seldom been tested in palliative care settings, and occupational well-being of palliative care professionals has never before been investigated in Croatia. Our aim was therefore to fill that gap by testing the JDCS model among Croatian nurses providing palliative care. More specifically, we wanted to see how job demands, job control, and social support at work affect occupational well-being outcomes (i.e. job satisfaction and burnout dimensions of exhaustion and disengagement from work) in terms of the model's iso-strain and buffer hypotheses. This cross-sectional study included 68 nurses working in various palliative care institutions across Croatia, who answered our online questionnaire. Overall, the nurses did not report high levels of burnout or low job satisfaction. The only significant effect was that of job control on job satisfaction $(\beta=0.38 ; \mathrm{P}<0.01)$ and disengagement $(\beta=-0.45$; $\mathrm{P}<0.01$ ), while job demands and social support at work had a significant interaction effect on the burnout dimension of exhaustion $(\beta=0.39 ; \mathrm{P}<0.01)$ in the sense that high social support at work buffered the increase in exhaustion associated with high job demands. These findings suggest that interventions aimed at increasing perceived job control and social support at the workplace could improve occupational well-being of nurses working in palliative care.
\end{abstract}

KEY WORDS: JDSC; mental health; occupational well-being; work stress

There is considerable empirical evidence that nurses are exposed to more intensive stress and are more likely to develop the burnout syndrome than other health care professionals (1-3) or other professions (4).

Burnout is one of the worst consequences of exposure to chronic occupational stress in caregiving professions, as it adversely affects not only the caregivers but the receivers as well. Burnout is usually described as having three dimensions: (a) emotional exhaustion (person's feeling that his or her emotional resources are exhausted which results in fatigue, decreased enthusiasm, and irritability), (b) depersonalisation (distancing, coldness, and negative and cynical attitudes towards clients/patients), and (c) sense of diminished personal and professional accomplishment (sense of incompetence and dissatisfaction with work achievement) $(5,6)$. Recently, Demerouti et al. (7) redefined burnout by reducing it to only two key dimensions exhaustion and disengagement from work - as they consider personal accomplishment to poorly correlate with the other two dimensions. As the result of intensive occupational stress, exhaustion covers various aspects besides the emotional, while disengagement from work is broader than depersonalisation, which refers primarily to a person's relationships with clients/patients. This is why we adopted this new definition of burnout in this study.

Corresponding author: Ivana Tucak Junaković, University of Zadar Department of Psychology Obala kralja Petra Krešimira IV 2, 23000 Zadar, Croatia, E-mail: itucak@unizd.hr
Besides burnout and related mental health problems such as anxiety or depression (8), other serious negative consequences of nurses' prolonged exposure to intensive stressors at work are decreased job satisfaction and high turnover intention. They can all incur additional cost to health organisations and compromise the quality of health care $(2,9-12)$. Job satisfaction is recognised as crucial in nurses' retention and low turnover intention (13). For the purpose of this study, job satisfaction is defined as a general, unidimensional construct or as "a positive (or negative) evaluative judgment one makes about one's job or job situation" (14).

Palliative care is a particularly demanding work environment for nurses due to prolonged exposure to patient suffering, pain, and death and to the grieving of family members. Palliative care profession is generally considered as highly stressful and subject to burnout, and nurses are considered to be in greater risk of developing the burnout syndrome and suffering other adverse health and well-being consequences than other palliative care professionals (15-18).

Even though empirical research in palliative care has been increasing recently $(11,18-27)$, most of it is limited by similar methodological constraints, such as relatively small participant samples, low response rates, and crosssectional research design. It is often pointed out that burnout, decreased job satisfaction, high turnover $(11,26$, 28 ), and other negative outcomes are common among nurses and other health professionals in palliative care setting, but 
there is little empirical evidence to support these statements. Quite the opposite, most research still shows that palliative care professionals, including nurses, experience similar or even lower levels of stress and burnout than health professionals working in other settings (for review see 15, 29-31). According to a recent systematic review with metaanalysis by Gómez-Urquiza et al. (15), the prevalence of different burnout dimensions among palliative care nurses is between $24 \%$ and $30 \%$. These are mainly associated with occupational (workload, work environment, relations with patients and family) and psychological factors (personality traits such as extroversion and neuroticism, meaning in life).

The most commonly used model in studying the effects of occupational stress on workers' health and occupational and general psychological well-being is a Job DemandsControl-Support (JDCS) model $(32,33)$. In palliative care settings, however, it has seldom been applied $(21,34)$. It explains the impact of three key job dimensions, i.e. job demands (e.g. time pressure, conflicting roles, complexity of working tasks), job control (e.g. decision authority, skill utilisation), and social support from coworkers and supervisors. According to the model's iso-strain hypothesis, employee's well-being is worst affected by a combination of high job demands, low job control, and low support (additive effect). The model's buffer hypothesis, in turn, predicts that higher social support and job control can moderate the negative impact of high job demands on employee's well-being (buffering/interactive effect). Many review articles have tested both hypotheses (35-37), but empirical evidence speaks in favour of the iso-strain hypothesis in the sense that the buffering effect of high social support and job control has not always been confirmed.

\section{Study aims}

The main aim of this cross-sectional study was to test how and to what extent job demands, job control, and social support from coworkers and supervisors would explain various aspects of occupational well-being, i.e. job satisfaction and burnout dimensions, in a sample of Croatian nurses providing palliative care. For the conceptual framework we used the JDCS model to see how the two hypotheses would fare in our sample. In accordance to the iso-strain hypothesis, we assumed that high job demands, low job control, and low social support would additively contribute to low job satisfaction and high exhaustion and disengagement from work as burnout dimensions. In accordance to the buffer hypothesis, we assumed that high levels of job control and social support would buffer, i.e. decrease, the negative impact of high job demands.

According to some estimations of ten years ago (38), Croatia was among the least developed EU countries in terms of palliative medicine. Since the recent adoption of an improved legal framework and development guidelines, it has seen a significant progress in palliative care, but to the best of our knowledge, this is the first study conducted among palliative care professionals in Croatia.

\section{PARTICIPANTS AND METHODS}

The study included 68 nurses (65 women and 3 men), who were part of a larger convenience sample of professionals of different profiles working in palliative care. Their average age was 41.5 years $(\mathrm{SD}=11.20$; range: $21-65$ years) and work experience in nursing 19 years and 10 months ( $\mathrm{SD}=11.19$ years; range: $1.3-41$ years), while their average work experience in palliative care was 4 years and 2 months ( $\mathrm{SD}=6$ years; range: 2 months -33.4 years). Fortythree reported to have a bachelor's degree in nursing, while the rest completed high school. Forty-three claimed to have completed additional training in palliative care. Forty-six were married at the time of the survey, and 56 had children.

\section{Data collection}

The data presented in this paper were collected with an online questionnaire as part of a larger study on the challenges of work in palliative care setting in Croatia, which included various professionals (nurses, physicians, physiotherapists, psychologists, social workers, and priests) working in palliative care. We sent out e-mails with a description of the research, link to the questionnaire, and an invitation to participate to all known institutions and facilities providing palliative care in Croatia and to the members of the Centre for Palliative Medicine, Medical Ethics, and Communication Skills (CEPAMET) and asked them to forward the information and the questionnaire link to employees who work in palliative care. We also explained research aims and methods to the heads of most of these institutions in person or over the phone in advance.

As we did not have accurate figures about how many palliative care nurses there were in Croatia, we could not rely on probabilistic sampling but resorted to convenience sampling instead. In addition, we did not want to limit participation by setting a minimal work experience in palliative care. The only condition for participation was that participants had been working in palliative care at the time of the study.

The participants were informed that participation was voluntary and anonymous, with no possibility to link answers to e-mail addresses or participants' identities. The study was approved by the Ethics Committee of the Zadar University Department of Psychology. Answers were collected from October 2018 to February 2019.

\section{JDCS model measures}

Job demands were measured with the Croatian translation of the short version of the Nursing Stress Scale (NSS) (10) adapted from the original 34-item NSS scale (39). It consists of five subscales most closely related to the 
demands and stressors in palliative care setting, as follows: work load (five items, e.g. Not enough time to provide emotional support to the patient), conflict (four items, e.g. Conflict with physician), uncertainty regarding patient treatment (four items, e.g. Not knowing what a patient or a patient's family ought to be told about the patient's condition and treatment), dealing with death and dying (three items, e.g. Watching a patient suffer), and inadequate preparation (three items, e.g. Feeling inadequately prepared to help with emotional needs of patient). Each item is scored on a four-point scale, from never (score 1) to very often (score 4), and the job demands measure is calculated as the average of the sum of scores for each subscale.

Job control was measured with the Job Control Subscale (40) from the Croatian adaptation of Karasek's Job Content Questionnaire (JCQ) (41). The subscale contains five statements (e.g. I have a complete control in doing my job), and answers range from strongly disagree (score 1) to strongly agree (score 7). The total score is the average of scores for all five items.

Social support from coworkers and supervisors was measured with the subscale assessing lack of support, taken from the short version of the revised NSS (10). This subscale consists of three items (e.g. Lack of opportunity to share experiences and feelings with other personnel in the unit) and answers vary from never (score 1) to very often (score 4 ). For the purpose of this study, the lack of support subscale's total score was inverted and reformulated in terms of social support at work.

\section{Occupational well-being measures}

Job satisfaction was measured with the Job Satisfaction Scale (42), which consists of five items (e.g. Ifeel satisfied with my present job) and scoring reflects the degree of agreement with each statement on a scale from 1 (strongly disagree) to 5 (strongly agree). The total score is the average of sums of all five statements. Higher score indicates higher job satisfaction.
Burnout was assessed with the Croatian translation (43) of the Oldenburg Burnout Inventory (44). It consists of 16 items across two subscales of eight, one assessing exhaustion (e.g. After my work, I usually feel worn out and weary) and the other disengagement from work (e.g. It happens more and more often that I talk about my work in a negative way). Scores range from 1 (strongly disagree) to 4 (strongly agree), and the total of each subscale is the average of the sums of eight items. Higher score indicates higher exhaustion or higher disengagement.

\section{RESULTS}

Table 1 shows the mean scores for all variables and their correlations. All the scales showed acceptable to good reliability (see Cronbach's alpha). Job demands were not rated as very stressful, while job control and social support were estimated as quite high. Participants also reported rather high job satisfaction while exhaustion and disengagement (burnout dimensions) were below scale average.

The correlations between JDCS variables and between occupational well-being variables (job satisfaction and the burnout variables) were significant, moderately high, and as expected. So were some of the correlations between the JDCS variables and the occupational well-being variables (e.g. between job demands and exhaustion or disengagement or between job control and satisfaction), while others were not significant.

To test the JDCS model hypotheses, we ran three hierarchical regression analyses by regressing job satisfaction, exhaustion, and disengagement against job demands, job control, and social support (Table 2). Job demands, control, and social support were entered in the first step, two-way interactions in the second step, and three-way interactions in the third step of regression analyses. We did not control for the background variables (age, marital and parental status, education, or work experience) for two reasons: first, in earlier analyses these

Table 1 JDCS and occupational well-being scores by palliative care nurses, internal consistency (Cronbach's alpha), and Pearson's correlations between variables $(\mathrm{N}=68)$

\begin{tabular}{lcccccccc} 
Variables & Mean & SD & Range & $\boldsymbol{\alpha}$ & $\mathbf{1}$ & $\mathbf{2}$ & $\mathbf{3}$ & $\mathbf{4}$ \\
\hline JDCS variables & & & & & & & & \\
\hline (1) Job demands & 2.23 & 0.55 & $1.05-4.00$ & 0.91 & --- & & & \\
\hline (2) Job control & 25.89 & 5.54 & $10-35$ & 0.82 & $-0.57^{* *}$ & --- & & \\
\hline (3) Social support & 3.00 & 0.76 & $1.00-4.00$ & 0.78 & $-0.72^{* *}$ & $0.31^{*}$ & --- &
\end{tabular}

Occupational well-

being variables

\begin{tabular}{llllllllll}
\hline (4) Job satisfaction & 3.89 & 0.60 & $2.00-5.00$ & 0.81 & -0.16 & $0.32^{* *}$ & 0.22 & -- & \\
\hline (5) Exhaustion & 2.27 & 0.47 & $1.25-3.25$ & 0.76 & $0.28^{*}$ & $-0.35^{* *}$ & -0.15 & $-0.52^{* *}$ & -- \\
\hline (6) Disengagement & 1.95 & 0.50 & $1.00-3.37$ & 0.81 & $0.28^{*}$ & $-0.45^{* *}$ & -0.22 & $-0.65^{* *}$ & $0.72^{* *}$ \\
\hline
\end{tabular}

$* P<0.05, * * P<0.01$ 


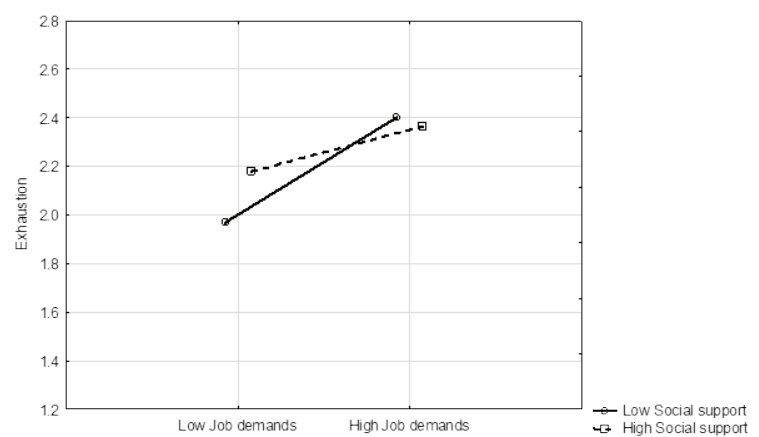

Figure 1 Interaction effect of job demands and social support on exhaustion

variables did not show any significant role in various aspects of occupational well-being of palliative care nurses (45) and, second, there would have been too many predictors in regression analyses for such a small sample.

The only significant effects we established were those of job control on job satisfaction and disengagement and of job demands and social support on exhaustion. Higher levels of control correlated with higher levels of job satisfaction and lower levels of disengagement from work.

Figure 1 shows that exhaustion in nurses who perceive low social support at work increases with job demands, yet this increase is significantly less pronounced when social support is high.

We found no evidence of a three-way interaction with JDCS dimensions. The proportion of explained variance of various occupational well-being outcomes in the final step of the analyses was low ( $9 \%$ for job satisfaction, $11 \%$ for exhaustion, and $18 \%$ for disengagement), which suggests that factors besides those included in this study may explain occupational well-being of nurses providing palliative care.

\section{DISCUSSION}

Our findings only partly confirm both hypotheses, as the only job aspect that significantly contributed to occupational well-being, more precisely to job satisfaction and disengagement, was job control. The importance of job control for occupational and personal well-being and health has been evidenced by numerous studies testing the JDCS model in different professional settings, including nursing (35-37, 46-48) and palliative care context $(21,34)$.

In addition, our two-way interaction analysis shows that social support at work buffers the adverse effect of job demands on exhaustion. This protective role of social support from coworkers and supervisors against the burnout syndrome and other negative consequences in the nursing

Table 2 Hierarchical regression analyses of JDCS variables and their two-way and three-way interactions as predictors of job satisfaction, exhaustion, and disengagement in palliative care nurses $(\mathrm{N}=68)$

\begin{tabular}{lccc}
\hline & Job satisfaction & Exhaustion & Disengagement \\
\hline Predictors & $\beta(\beta)$ & $\beta(\beta)$ & $\beta(\beta)$ \\
\hline Step 1: & & & \\
Demands & $0.27(0.18)$ & $0.17(0.29)$ & $-0.06(0.00)$ \\
Control & $0.38^{* *}(0.34)$ & $-0.27(-0.32)$ & $-0.45^{* *}\left(-0.40^{* *}\right)$ \\
Social support & $0.29(0.22)$ & $0.06(0.06)$ & $-0.12(-0.03)$ \\
\hline$R^{2}$ & $0.14^{*}$ & $0.13^{*}$ & $0.21^{* * *}$ \\
Adj $R^{2}$ & $0.10^{*}$ & $0.09^{*}$ & $0.17^{* * *}$ \\
$F(3,64)$ & $3.57^{*}$ & $3.23^{*}$ & $5.61^{* *}$ \\
\hline Step $2:$ & & & $0.06(0.09)$ \\
Demands x Control & $0.02(0.01)$ & $0.08(0.06)$ & $0.30(0.42)$ \\
Demands x Social support & $-0.32(-0.35)$ & $0.39^{* *}(0.31)$ & $0.21(0.18)$ \\
Control x Social support & $-0.28(-0.27)$ & $0.35(0.37)$ & 0.04 \\
\hline$R^{2}$ & 0.04 & 0.06 & $0.25^{* *}$ \\
$R^{2}$ & $0.18^{*}$ & $0.19^{*}$ & $0.17^{* *}$ \\
Adj $R^{2}$ & $0.10^{*}$ & $0.11^{*}$ & $3.33^{* *}$ \\
$F(6,61)$ & $2.25^{*}$ & $2.39^{*}$ & $0.27(0.27)$ \\
\hline Step 3: & & & 0.02 \\
Demands x Control x Social support & $-0.08(-0.08)$ & $-0.20(-0.20)$ & $0.26^{* *}$ \\
\hline$\Delta R^{2}$ & 0.00 & 0.01 & $0.18^{* *}$ \\
$R^{2}$ & 0.18 & 0.20 & $3.08^{* *}$ \\
Adj $R^{2}$ & 0.09 & 0.11 & 2.15 \\
$F(7,60)$ & 1.92 & & \\
\hline$P<0.05, * *<.01$ & & \\
\hline
\end{tabular}

${ }^{*} P<0.05,{ }^{* *} P<0.01,{ }^{* * *} P<0.001,(\beta)-\beta$ coefficient at the final step 
profession has been well documented $(24,49)$. Nursing requires good cooperation and teamwork (50), especially in demanding work settings such as palliative care.

Our three-way interaction analysis of JDCS aspects did not reveal any effect on either job satisfaction or the burnout dimensions. Other studies have shown good support for the iso-strain hypothesis, which predicts the worst well-being and health outcomes for employees in various occupations, including nursing, who experience high job demands, low control and low support at work, while there is only scarce evidence for the interactive influence of JDCS dimensions, i.e. for the buffer effect of job control and social support at work (35-37).

The shortcomings of this study are primarily related to the small convenience sample, which is the consequence of poor response rate, a common problem in this field of research. Small sample size entails small statistical power, and many regression coefficients that were slightly below the significance level would probably turn out to be significant in larger sample.

We should also take into account bias, as nurses who agreed to participate were generally satisfied with their job, and nurses who did not participate may have perceived their work as highly stressful (non-response bias).

The additional problem could be that JDCS components are too broad in concept to be specific enough for palliative care nursing. Future research in palliative care nursing could therefore benefit from tailoring the all too general JDCS model to accommodate variables and measures that better reflect the specifics of palliative care nursing. Future research should also take into account individual characteristics (e.g. resilience, spirituality, finding meaning in death, coping mechanisms), which may help to understand the impact of stress in palliative care on nurses' mental health and well-being.

Despite its limitations, this is the first empirical research in Croatia addressing the challenges of work in palliative care setting. Consistent with some earlier findings $(15,29$, 31), it shows rather high levels of occupational well-being (i.e. quite high job satisfaction and rather low levels of exhaustion and disengagement) in Croatian palliative care nurses. However, further research on the mental health and occupational well-being of palliative care nurses is needed to verify these findings.

To conclude, the results of our study have confirmed the significant effect of job control on job satisfaction and disengagement and significant buffer effect of social support at work, which can lower the negative impact of job demands on occupational well-being outcomes in nurses providing palliative care. Therefore, practical interventions should focus on strengthening supportive interpersonal relations at work and enhancing perceived job control among nurses by letting them to participate more in decision-making about the organisational aspects of the job and patient treatment.

\section{Acknowledgements}

We thank the Centre for Palliative Medicine, Medical Ethics, and Communication Skills (CEPAMET) in Croatia for the assistance in conducting this research. We also thank all study participants for taking the time to answer our questionnaire.

\section{Conflicts of interest}

None to declare.

\section{REFERENCES}

1. Cañadas-De la Fuente GA, Vargas C, San Luis C, García I, Cañadas GR, De la Fuente E I. Risk factors and prevalence of burnout syndrome in the nursing profession. Int J Nurs Stud 2015;52:240-9. doi: 10.1016/j.ijnurstu.2014.07.001

2. Moustaka E, Constantinidis TC. Sources and effects of workrelated stress in nursing. Health Sci J 2010;4:210-6.

3. Wu H, Chi T, Chen L. Occupational stress among hospital nurses: cross sectional survey. J Adv Nurs 2010;66:627-34. doi: 10.1111/j.1365-2648.2009.05203.x

4. Chan KB, Lai G, Ko YC, Boey KW. Work stress among six professional groups: the Singapore experience. Soc Sci Med 2000;50:1415-32. doi: 10.1016/s0277-9536(99)00397-4

5. Maslach C, Jackson SE. The measurement of experienced burnout. J Organ Behav 1981;2:99-113. doi: 10.1002/ job.4030020205

6. Maslach C, Schaufeli WB, Leiter MP. Job burnout. Annu Rev Psychol 2001;52:397-422. doi: 10.1146/annurev. psych.52.1.397

7. Demerouti E, Mostert K, Bakker AB. Burnout and work engagement: a thorough investigation of the independency of both constructs. J Occup Health Psychol 2010;15:209-22. doi: $10.1037 / \mathrm{a} 0019408$

8. Koutsimani P, Montgomery A, Georganta K. The relationship between burnout, depression, and anxiety: A systematic review and meta-analysis. Front Psychol 2019;10:284. doi: 10.3389/fpsyg.2019.00284

9. Alharbi AA, Dahinten VS, MacPhee M. The relationships between nurses' work environments and emotional exhaustion, job satisfaction, and intent to leave among nurses in Saudi Arabia. J Adv Nurs 2020;76:3026-38. doi: 10.1111/ jan. 14512

10. Dagget T, Molla A, Belachew T. Job related stress among nurses working in Jimma Zone public hospitals, South West Ethiopia: a cross sectional study. BMC Nurs 2016;15:39. doi: 10.1186/s12912-016-0158-2

11. Head B, Middleton A, Zeigler C. Work satisfaction among hospice and palliative nurses. J Hosp Palliat Nurs 2019;21:E111. doi: 10.1097/NJH.0000000000000562

12. Van Bogaert P, Van Heusden D, Timmermans O, Franck E. Nurse work engagement impacts job outcome and nurseassessed quality of care: model testing with nurse practice environment and nurse work characteristics as predictors. Front Psychol 2014;5:1261. doi: 10.3389/fpsyg.2014.01261

13. Lu H, While AE, Barriball KL. Job satisfaction among nurses: a literature review. Int J Nurs Stud 2005;42:211-27. doi: 10.1016/j.ijnurstu.2004.09.003 
14. Weiss HM. Deconstructing job satisfaction: separating evaluations, beliefs and affective experiences. Hum Resour Manag Rev 2002;22:173-94. doi: 10.1016/S10534822(02)00045-1

15. Gómez-Urquiza JL, Albendín-García L, Velando-Soriano A, Ortega-Campos E, Ramírez-Baena L, Jose MembriveJiménez M, Suleiman-Martos N. Burnout in palliative care nurses, prevalence and risk factors: A systematic review with meta-analysis. Int J Environ Res Public Health 2020;17:7672. doi: 10.3390/ijerph17207672

16. Horn DJ, Johnston CB. Burnout and self care for palliative care practitioners. Med Clin North Am 2020;104:561-72. doi: 10.1016/j.mena.2019.12.007

17. Mehta DH, Perez GK, Traeger L, Park ER, Goldman RE, Haime V, Chittenden EH, Denninger JW, Jackson VA. Building resiliency in a palliative care team: a pilot study. J Pain Symptom Manag 2016;51:604-8. doi: 10.1016/j. jpainsymman.2015.10.013

18. Wang C, Grassau P, Lawlor PG, Webber C, Bush SH, Gagnon B, Kabir M, Spilg EG. Burnout and resilience among Canadian palliative care physicians. BMC Palliat Care 2020;19:169. doi: 10.1186/s12904-020-00677-z

19. Desbiens J-F, Fillon L. Coping strategies, emotional outcomes and spiritual quality of life in palliative care nurses. Int J Palliat Nurs 2007;13:291-300. doi: 10.12968/ ijpn.2007.13.6.23746

20. Ercolani G, Varani S, Peghetti B, Franchini L, Malerba MB, Messana R, Sichi V, Pannuti R, Pannuti F. Burnout in home palliative care: What is the role of coping strategies? J Palliat Care 2020;35:46-52. doi: 10.1177/0825859719827591

21. Fillion L, Tremblay I, Truchon M, Côté D, Ward Struthers C, Dupuis R. Job satisfaction and emotional distress among nurses providing palliative care: empirical evidence for an integrative occupational stress-model. Int J Stress Manag 2007;14:1-25. doi: 10.1037/1072-5245.14.1.1

22. Frey R, Robinson J, Wong C, Gott M. Burnout, compassion fatigue and psychological capital: Findings from a survey on nurses delivering palliative care. Appl Nurs Res 2018;43:19. doi: 10.1016/j.apnr.2018.06.003

23. Jackson V, Mack J, Matsuyama R, Lakoma MD, Sullivan AM, Arnold RM, Weeks JC, Block SD. A qualitative study of oncologists' approaches to end-of-life care. J Palliat Med 2008;11:893-906. doi: 10.1089/jpm.2007.2480

24. Kalicińska M, Chylińska J, Wilczek- Różyczka E. Professional burnout and social support in the workplace among hospice nurses and midwives in Poland. Int J Nurs Pract 2012;18:595-603. doi: 10.1111/ijn.12003

25. Koh MYH, Chong PH, Neo PSH, Ong YJ, Yong WC, Ong WY, Shen MLJ, Hum AYM. Burnout, psychological morbidity and use of coping mechanisms among palliative care practitioners: A multi-centre cross-sectional study. Palliat Med 2015;29:633-42. doi: 10.1177/0269216315575850

26. Kamal AH, Bull JH, Wolf SP, Swetz KM, Shanafelt TD, Ast K, Kavalieratos D, Sinclair CT, Abernethy AP. Prevalence and predictors of burnout among hospice and palliative care clinicians in the U.S. J Pain Symptom Manag 2016;51:690 6. doi: 10.1016/j.jpainsymman.2015.10.020

27. Rizo-Baeza M, Mendiola-Infante SV, Sepehri A, Palazón-Bru A, Gil-Guillén VF, Cortés-Castell E. Burnout syndrome in nurses working in palliative care units: an analysis of associated factors. J Nurs Manag 2018;26:19-25. doi: 10.1111/jonm.12506
28. Miller PE. The relationship between job satisfaction and intention to leave of hospice nurses in a for-profit corporation. J Hosp Palliat Nurs 2008;10:56-64. doi: 10.1097/01. NJH.0000306711.65786.75

29. Martins Pereira S, Fonseca AM, Carvalho AS. Burnout in palliative care: a systematic review. Nurs Ethics 2011;18:31726. doi: $10.1177 / 0969733011398092$

30. Peters L, Cant R, Sellick K, O'Connor M, Lee S, Burney S, Karimi L. Is work stress in palliative care nurses a cause for concern? A literature review. Int J Palliat Nurs 2012;18:5617. doi: 10.12968/ijpn.2012.18.11.561

31. Parola V, Coelho A, Cardoso D, Sandgren A, Apóstolo J. Burnout in palliative care settings compared with other settings: A systematic review. J Hosp Palliat Nurs 2017;19:442-51. doi: 10.1097/NJH.0000000000000370

32. Johnson JV, Hall EM. Job strain, work place social support, and cardiovascular disease: a cross-sectional study of a random sample of the Swedish working population. Am J Public Health 1988;78:1336-42. doi: 10.2105/ ajph.78.10.1336

33. Karasek RA, Theorell T. Healthy Work, Stress, Productivity, and the Reconstruction of Working Life. New York (NY): Basic Books; 1990.

34. Fillion L, Desbiens JF, Truchon M, Dallaire C, Roch G. Le stress au travail chez les infirmières en soins palliatifs de fin de vie selon le milieu de pratique [Stress at work in nurses providing end-of-life palliative care according to care settings, in French]. Psycho-Oncol 2011;5:127-36. doi: 10.1007/s11839-011-0321-7

35. de Lange AH, Taris TW, Kompler MAJ, Houtman ILD, Bongers PM. "The very best of the millennium": longitudinal research and the demand-control-(support) model. J Occup Health Psychol 2003;8:282-305. doi: 10.1037/10768998.8.4.282

36. Häuser JA, Mojzisch A, Niesel M, Schulz-Hardt S. Ten years on: a review of recent research on the job demand-control (-support) model and psychological well-being. Work Stress 2010;24:1-35. doi: 10.1080/02678371003683747

37. Van der Doef M, Maes S. The job demand-control(-support) model and psychological well-being: a review of 20 years of empirical research. Work Stress 1999;13:87-114. doi: 10.1080/026783799296084

38. Brkljačić M. Aktualno stanje palijativne skrbi u Hrvatskoj [Current state of palliative care in Croatia, in Croatian]. Služba Božja 2013;53:367-76.

39. Gray-Toft P, Anderson JG. The Nursing Stress Scale: development of an instrument. J Psychopathol Behav Assess 1981;3:11-23. doi: 10.1007/BF01321348

40. Gregov Lj, Šimunić A, Nikolić M. Skala psiholoških zahtjeva $i$ kontrole posla [The psychological demands and job control scale, in Croatian]. In: Proroković A, Ćubela Adorić V, Penezić Z, Tucak Junaković I, editors. Zbirka psihologijskih skala i upitnika. Svezak 6. Zadar (Croatia): University of Zadar; 2012. p.13-8.

41. Karasek RA, KARASEK R, Karasek RA, Karasek R, Gordon-Strachan G, Pietrowsky C, Frese M, Pieper CF, Schwartz GJ. Job Content Questionnaire and User's Guide. Lowell: University of Massachusetts Lowell, The Job Content Questionnaire Center; 1985.

42. Judge TA, Thoresen CJ, Bono JE, Patton, GK. The job satisfaction-job performance relationship: a qualitative and 
quantitative review. Psychol Bull 2001;127:376-407. doi: 10.1037/0033-2909.127.3.376

43. Burić I, Slišković A. Oldenburški upitnik sagorijevanja [The Oldenburg Burnout Inventory, in Croatian]. In: Slišković A, Burić I, Ćubela Adorić V, Nikolić M, Tucak Junaković I, editors. Zbirka psihologijskih skala i upitnika. Svezak 9. Zadar (Croatia): University of Zadar; 2018. p. 13-9.

44. Demerouti E, Bakker AB. The Oldenburg Burnout Inventory: a good alternative to measure burnout and engagement. In: Halbesleben J, editor. Stress and burnout in Health Care. Nova Sciences: Hauppauge; 2008. p. 65-78.

45. Tucak Junaković I, Macuka I, Skokandić L. Profesionalni stres, zadovoljstvo poslom i sagorijevanje medicinskih sestara / tehničara zaposlenih u području palijativne skrbi [Occupational stress, job satisfaction and burnout in palliative care nurses, in Croatian]. Med Jad 2019;49:157-71.

46. Ariza-Montes A, Arjona-Fuentes JM, Han H, Law R. Work environment and well-being of different occupational groups in hospitality: Job Demand-Control-Support model. Int J Hosp Manag 2018;73:1-11. doi: 10.1016/j.ijhm.2018.01.010
47. Asif F, Javed U, Janjua SY. The job demand-control-support model and employee wellbeing: A meta-analysis of previous research. Pakistan J Psychol Res 2018;33:203-21.

48. Bagheri Hossein Abadi M, Taban E, Khanjani N, Naghavi Konjin Z, Khajehnasiri F, Samaei SE. Relationships between job satisfaction and job demand, job control, social support, and depression in Iranian nurses. J Nurs Res 2021;29:e143. doi: 10.1097/jnr.00000000000000410

49. Velando-Soriano A, Ortega-Campos E, Gómez-Urquiza JL, Ramírez-Baena L, De La Fuente EI, Cañadas-De la Fuente GA. Impact of social support in preventing burnout syndrome in nurses: A systematic review. Jpn J Nurs Sci 2020;17:e12269. doi: 10.1111/jjns.12269

50. Navajas-Romero V, Ariza-Montes A, Hernández-Perlines F. Analyzing the job demands-control-support model in worklife balance: A study among nurses in the European context. Int J Environ Res Public Health 2020;17:2847. doi: 10.3390/ ijerph17082847

\section{Zahtjevi i kontrola posla te socijalna podrška kao prediktori zadovoljstva i izgaranja na poslu medicinskih sestara/ tehničara zaposlenih u području palijativne skrbi u Hrvatskoj}

Ispitivanja Modela zahtjeva-kontrole posla-socijalne podrške (JDCS) u kontekstu palijativne skrbi doista su rijetka. Uz to, nedostaju istraživanja profesionalne dobrobiti zaposlenih u području palijativne skrbi u Hrvatskoj. Stoga je cilj ovoga istraživanja bio testirati JDCS model među hrvatskim medicinskim sestrama/tehničarima zaposlenima u području palijativne skrbi. Točnije, pokušali smo provjeriti kako zahtjevi i kontrola posla te socijalna podrška na radnome mjestu utječu na profesionalnu dobrobit (tj. zadovoljstvo poslom i dimenzije izgaranja-iscrpljenost i otuđenost) u kontekstu tzv. iso-strain i buffer hipoteza. U presječnom istraživanju sudjelovalo je 68 medicinskih sestara/tehničara zaposlenih u različitim institucijama koje pružaju palijativnu skrb u Hrvatskoj. Podatci su prikupljeni ispunjavanjem online upitnika. Ukupno gledano, medicinske sestre/tehničari nisu izvijestili o visokim razinama profesionalnog izgaranja ili o niskom zadovoljstvu poslom u području palijativne skrbi. Rezultati su potvrdili značajan učinak kontrole posla u objašnjenju zadovoljstva poslom $(\beta=0,38 ; \mathrm{P}<0,01)$ i otuđenosti $(\beta=-0,45 ; \mathrm{P}<0,01)$, a zahtjevi posla i socijalna podrška na poslu pokazali su značajan interakcijski učinak na iscrpljenost kao dimenziju izgaranja $(\beta=0,39 ; \mathrm{P}<0,01)$ na način da visoka socijalna podrška usporava porast iscrpljenosti povezane s visokim zahtjevima posla. Rezultati ovoga istraživanja impliciraju da bi intervencije usmjerene na povećanje percipirane kontrole posla i socijalne podrške na radnome mjestu mogle poboljšati profesionalnu dobrobit medicinskih sestara/tehničara zaposlenih u palijativnoj skrbi.

KLJUČNE RIJEČI: JDCS model; mentalno zdravlje; profesionalna dobrobit; radni stres 